\title{
Land use and groundwater quality: The case of Baixo Acaraú Irrigated Perimeter, Brazil ${ }^{1}$
}

\author{
Uso da terra e qualidade das águas subterrâneas: caso do Perímetro Irrigado Baixo \\ Acaraú, Brasil
}

\author{
Eunice Maia de Andrade ${ }^{2 *}$, Fernando Bezerra Lopes ${ }^{3}$, Helba Araújo Queiroz Palácio ${ }^{4}$, Deodato do Nascimento \\ Aquino $^{5}$ e Deborah Mithya Barros Alexandre ${ }^{6}$
}

\begin{abstract}
The aim of this work was to identify and to investigate the determining factors of water table quality in the Irrigated Perimeter of Baixo Acaraú, Ceará, Brazil, using factor analysis/principal component analysis (FA/PCA). It was sampled nine shallow wells spread out on two different types of land: uncultivated area (A1) and irrigated area (A2). Groundwater was sampled monthly from Dec/2003 to Nov/2005, Nov/2006, Mar and April/2007. We measured the following parameters: $\mathrm{pH}$, electrical conductivity (EC), and concentrations of $\mathrm{Na}^{+}, \mathrm{Ca}^{2+}, \mathrm{Mg}^{2+}, \mathrm{K}^{+}, \mathrm{Cl}^{-}, \mathrm{PO}_{4}^{-}, \mathrm{NH}_{4}^{-}, \mathrm{NO}_{3}^{-}, \mathrm{SO}_{4}^{-2}, \mathrm{HCO}_{3}^{-}$and $\mathrm{CO}_{3}^{-2}$. The PCA resulted in a model composed of three components that explained $93.06 \%$ and $83.72 \%$ of the total variance of the data set from A1 and A2, respectively. It was found that the determining factors of water quality were the mineralization processes and anthropogenic activities in both areas. The anthropogenic activities in the irrigated area were related to nitrogenous fertilizers, while those in the uncultivated area were associated with the presence of septic tanks (from the lack of sewage treatment).
\end{abstract}

Keywords - Anthropic action-fertilizer. Shallow wells. Irrigation-water contamination.

Resumo - O objetivo deste trabalho foi identificar os fatores que influenciam na qualidade das águas subterrâneas do Perímetro Irrigado Baixo Acaraú, Ceará, usando a técnica de estatística multivariada Análise Fatorial/Análise da Componente Principal (AF/ACP). Para avaliar a qualidade das águas no lençol freático, foram selecionados nove poços distribuídos aleatoriamente no Perímetro Irrigado em duas áreas: A1 - áreas não cultivadas; e A2 - áreas de cultivos irrigados. As amostras das águas foram coletadas mensalmente no período de dezembro de 2003 a novembro de 2005, em novembro 2006 e, em março e maio de 2007, encaminhadas ao laboratório, onde foram analisados os seguintes atributos: $\mathrm{pH}$, condutividade elétrica (CE), $\mathrm{Na}^{+}, \mathrm{Ca}^{2+}, \mathrm{Mg}^{2+}$, $\mathrm{K}^{+}, \mathrm{Cl}^{-}, \mathrm{PO}_{4}^{-}, \mathrm{NH}_{4}^{-}, \mathrm{NO}_{3}^{-}, \mathrm{SO}_{4}^{-2}, \mathrm{HCO}_{3}^{-} \mathrm{e} \mathrm{CO}_{3}^{-2}$. O emprego da AF/ACP resultou em um modelo composto por três componentes explicando 93,06 e 83,72\%, da variância total, respectivamente, para as áreas A1 e A2. Os fatores que influenciam na qualidade das águas subterrâneas, em ambas as áreas, foram definidos pelo processo natural de intemperismo geológico do solo e da ação antrópica. Nas áreas de cultura irrigada, a ação antrópica foi determinada por um fator relacionado aos nutrientes nitrogenados e correções de acidez dos solos. Nas áreas não cultivadas, a ação antrópica foi definida por um fator de saneamento básico (uso de fossas sépticas com lançamentos diretos ao solo). O manejo adotado nas áreas irrigadas do Distrito de Irrigação do Baixo Acaraú está contribuindo para um aumento gradual nas concentrações de nitrato em águas do lençol freático.

Palavras-chave - Ação antrópica-fertilizantes. Poços rasos. Irrigação-contaminação hídrica.

\footnotetext{
* Corresponding author

${ }^{1}$ Received 31/07/2009; accepted 13/04/2010

Pesquisa financiada pelo CNPq, Edital Universal 2002

2Departamento de Engenharia Agrícola/UFC, Caixa Postal 6.003, Fortaleza-CE, Brasil, 60455-970, Fone: (85) 3366.9762, eandrade@pq.cnpq.br

${ }^{3}$ Programa de Pós-Graduação em Engenharia Agrícola, UFC, Fortaleza-CE, Brasil, lopesfb@yahoo.com.br

${ }^{4}$ Instituto Federal de Educação Ciências e Tecnologia do Ceará/IFCE , Campus Iguatu, Sítio Cajazeiras-CE, Brasil, helbaraujo23@yahoo.com.br

${ }^{5}$ Instituto Nacional de Colonização e Reforma Agrária, Teresina-PI, Brasil, deoagro@yahoo.com.br

${ }^{6}$ Companhia de Gestão dos Recursos Hídricos/COGERH, Fortaleza-CE, Brasil, deborahm_barros@yahoo.com.br
} 


\section{Introduction}

Human occupation and land use change the biological, physical and chemical processes of the surrounding ecosystem (ANDRADE et al., 2007); these alterations can be evaluated by monitoring the water quality (MONTEIRO; PINHEIRO, 2004) of the ecosystem. To examine deeper the influence of anthropogenic activities on water quality, scientists have focused on studying irrigated agriculture, the main consumer and one of the main polluters of water bodies, both surface and groundwater (DOWD et al., 2008; MULLER et al., 2007; FENG et al., 2005).

Until the 1970s, it was believed that the soils and sub soils worked as filters, retaining the contaminants before they could reach the groundwater. However, more recently, it was verified that the contaminants can, in fact, reach groundwater (AQUINO et al., 2008; MINDRISZ, 2006). The chemical composition of the groundwater is the resultant of the composition of the water that percolates through the soil and the chemical makeup that directly develops by way of the local lithology. The local lithology defines the concentration of the substances dissolved in the water; this concentration increases as the water penetrates through the profile of the soil.

Groundwater constitutes a strategic reserve. Today, it represents a competitive factor in the global market. The contamination of groundwater through anthropogenic activity, especially in the semiarid regions, has resulted in the abandonment of many wells and the degradation of important aquifer areas (ANDRADE et al., 2009).

The Brazilian semiarid region is characterized by short periods of rainfall followed by long periods of drought. This intercalation results in constant alterations in the volume and in the chemical and physical characteristics of the water bodies in this region. During the rainfall period, part of the precipitation transforms into reposition water, which washes out the salts from the soil, leaching them to the saturated zones. Depending on the degree of circulation within the aquifer, the lixiviated salts tend to be carried away naturally from the superficial layers, accounting for their dilution in groundwater. The concentration of salts in the water from the water table can be determined by many factors. Two of the most prominent are the dissolution and the evaporation processes. The dissolution of salts in rocks is an equilibrium process between the concentration of salts in the rock and the concentration of salts in the circulating water; the slower the circulation, the longer the time of contact, and therefore, the higher the quantity of salts in the water of the aquifer.
Monitoring the dynamics of the elements in groundwater is difficult due to the sheer number of variables involved. The most commonly used method today to tackle classical problems of factorial analysis, such as understanding water quality data, is multivariate analysis (ANDRADE et al., 2008; HELENA et al., 2008; PALÁCIO et al., 2008) or, in particular, the method of principal components. The method of principal components reduces the dimensions of the data, as well as the number of variables involved, facilitating the extraction of relevant information.

The objective of this work was to use the principal component analysis to identify the physical and chemical characteristics of the groundwater quality of the Irrigated District of Baixo Acaraú, Ceará, which has experienced the impact of human land use.

\section{Materials and methods}

Samples were taken from the Baixo Acaraú Irrigation District (DIBAU) aquifer, which is located in the lower part of the Acaraú and Litorânea watersheds in Ceará, Brazil (Figure 1). The weather in the area is hot and humid with summer-autumn rains and the registered monthly average temperatures are greater than $18{ }^{\circ} \mathrm{C}$. The rainfall distribution is unimodal and strongly concentrated in the autumn months (March to May). As a general rule, more than $80 \%$ of the annual rainfall occurs during that period, even though the rainfall season ends in June. The mean annual rainfall is $960 \mathrm{~mm}$ and the potential annual evaporation is 1600 $\mathrm{mm}$. The geology of the area is represented by the Teriaria formation, Grupo Barreiras (Barriers Group), which is characterized by a few consolidated deposits. (MATIAS FILHO al., 2001).

A total of $80 \mathrm{~kg} \mathrm{ha}^{-1}$ of nitrogen in the form of urea and $36 \mathrm{~kg} \mathrm{ha}^{-1}$ of $\mathrm{KCl}$ were applied to the irrigated area through sprinkler irrigation (fertigation) per year. Also, $130 \mathrm{~kg} \mathrm{ha}^{-1}$ of nitrogen in the form of cow manure plus $300 \mathrm{~kg} \mathrm{ha}^{-1}$ of nitrogen in the form of chicken manure were applied during the growing season. The manure was applied on four occasions during the year. A total of $1500 \mathrm{~kg} \mathrm{ha}^{-1}$ of $\mathrm{CaCO}_{3}$ was uniformly incorporated in the soil.

To evaluate the water quality of the DIBAU aquifer, monthly water samples (Dec/2003 to Nov/2005, Nov/2006, Mar and April/2007) were taken from nine shallow wells (P1, P2, P3, P4, P5, P6, P7, P8 and P9) during a 27 month period (Figure 1). All nine sampled points were used for human consumption. The wells were spread out over two different types of land use: uncultivated area 


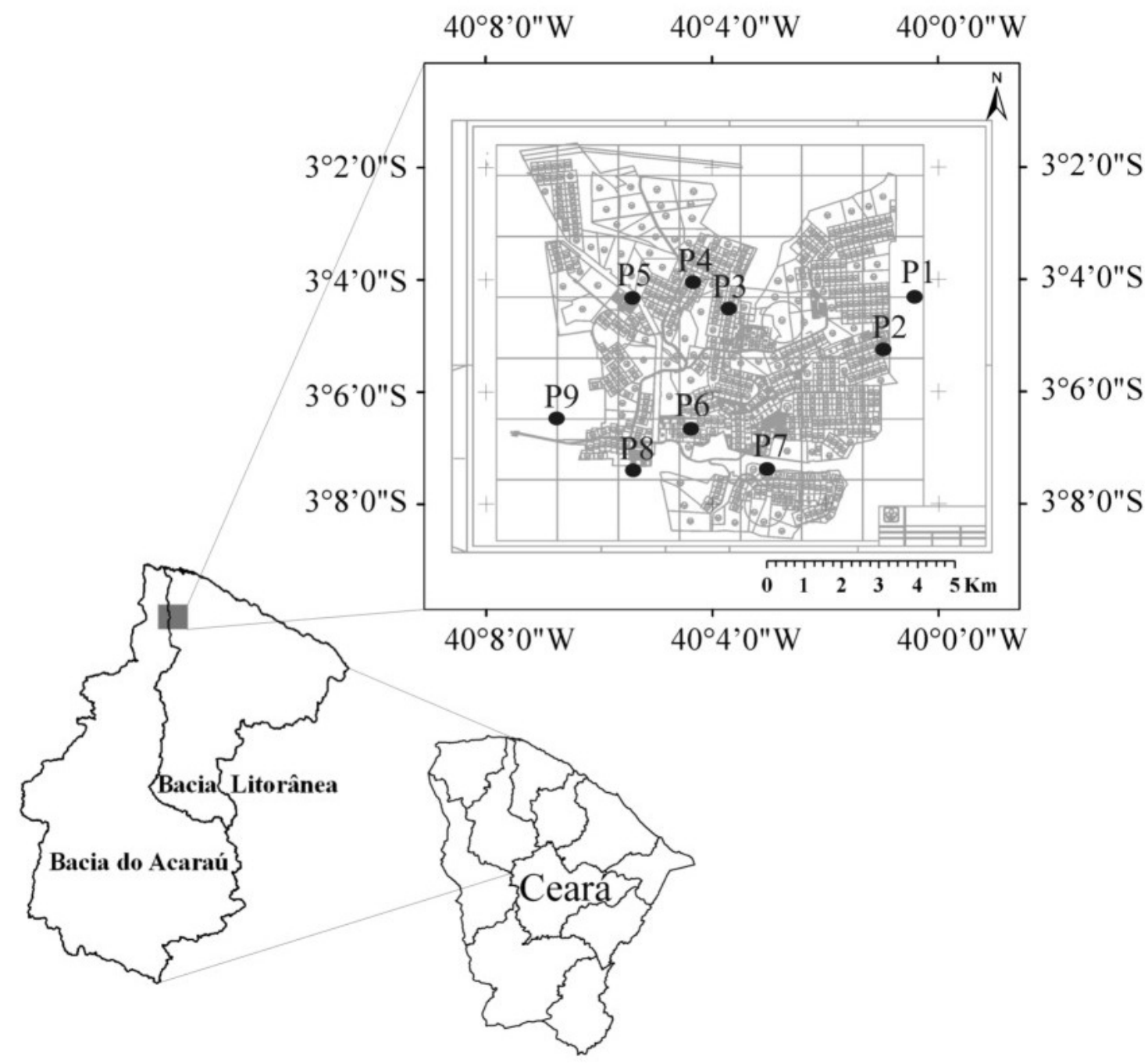

Figure 1 - Studied area location

(A1) and irrigated area (A2). Only wells P3 and P4 were directly influenced by irrigation practices and management. The sampling, preservation and transportation of the water samples to the laboratory were carried out using standard methods described by Richards (1954). The samples were analyzed for the following 13 parameters: $\mathrm{pH}$, electrical conductivity (EC), and concentrations of calcium $\left(\mathrm{Ca}^{2+}\right)$, magnesium $\left(\mathrm{Mg}^{2+}\right)$, sodium $\left(\mathrm{Na}^{+}\right)$, potassium $\left(\mathrm{K}^{+}\right)$, bicarbonate $\left(\mathrm{HCO}_{3}^{-}\right)$, phosphate $\left(\mathrm{PO}_{4}^{-2}\right)$, chloride $\left(\mathrm{Cl}^{-}\right)$, ammonium $\left(\mathrm{NH}_{4}^{+}\right)$, nitrate $\left(\mathrm{NO}_{3}^{-}\right)$, sulfate $\left(\mathrm{SO}_{4}^{-2}\right)$ e carbonate $\left(\mathrm{CO}_{3}^{-2}\right)$.

FA/PCA provided information on the most meaningful parameters, allowing data reduction to be rendered with minimum loss of original information (DILLON; GOLDSTEIN, 1984). In this study, the factors were estimated from principal component methods. The number of factors, called principal components (PCs), was defined according to the criterion that only those factors that accounted for variances greater than 1 (eigenvalue-one criterion) were included. The rationale for this criterion is that any component should account for more variance than any single variable in the standardized test score space.

After the correlation matrix definition, the appropriateness of the factor model was evaluated. A measure of sampling adequacy was computed using the Kayser Mayer Olkim (KMO) index, which compares the magnitude of the observed correlation coefficients to the magnitude of the partial correlation coefficients. If variables shared common factors, the partial correlation coefficients between pairs of variables were small when the linear effects of the other variables were eliminated. The factor analysis model was acceptable when KMO > 0.5 (MONTEIRO; PINHEIRO, 2004; HAIR JÚNIOR et al., 2005). 
The first principal component accounted for the largest amount of the total variation in the data. The second one was a weighted linear combination of the observed variables, which was uncorrelated with the first linear combination and which accounted for the maximum amount of the remaining total variation not already accounted for by the first one. The successive components were the weighted linear combinations of the remaining observed variables, all of which had the largest variance of all linear combinations and were uncorrelated with all previously extracted principal components (DILLON; GOLDSTEIN, 1984).

According to Norusis (1990), the factor analysis (FA) model appears somewhat similar to a multiple regression equation. Each variable is expressed as a linear combination of factors, which are not actually observed. In general, the model for the standardized variable is written as:

$$
X_{i}=a_{i 1} F_{1}+a_{i 2} F_{2}+\ldots+a_{i n} F_{n}+e
$$

Where the F's are the common factors, the A's the constants used to combine the $\mathrm{k}$ factors, and $\mathrm{U}$ is the unique factor. The unique factors are assumed to be uncorrelated with each other and with the common factors.

Althoughthe factormatrix obtainedinthe extraction phase elucidates the relationship between the factors and the individual variables, it is usually difficult to identify meaningful factors based on this matrix. Interpretation of the matrix may be easier using the rotation procedure. Rotation does not affect the goodness of fit of a factor solution. That is, although the factor matrix changes, the communalities and the percentage of total variance explained, do not change. The rotation process in factor analysis allows flexibility by presenting multiple views of the same data set (MONTEIRO; PINHEIRO, 2004). Varimax rotation, which is frequently applied to increase the participation of the variables with higher contribution and reduce those with lesser contributions, was adopted in this study. In this study, PCAs were subjected to raw Varimax rotation (VF). The statistical treatments used were performed using the software package SPSS 16.0 for Windows.

\section{Results and discussion}

\section{Principal component analysis}

The best model had a high KMO and the highest percent of total variance accounted in a smaller number of factors. It had three PCs with an eigenvalue $>1$ in both areas we studied. Table 1 shows the number of extracted components, the percent variance and the factor loadings on the variables for A1 (uncultivated area) and A2 (irrigated area). On A1 and A2, three-component-model explained, respectively, $93.06 \%$ and $83.72 \%$ of the total variance. The results are consistent with that reported by Palacio et al. (2008). These authors used a 13-parameter model to analyze samples from the river Trussu in Brazil and found that $83.43 \%$ of the total variance was concentrated in the first two components.

Sometimes the meaningful factors are hard to be identified due to the presence of intermediate values in the factor matrix (DILLON; GOLDSTEIN, 1984). However, by using a rotation procedure, interpreting the matrix becomes much easier. Rotation does not affect the goodness of fit of a factor solution. Although the factor matrix changes, the communalities and the percentage of total variance explained, does not change. Previous studies (ANDRADE et al., 2007; ANDRADE et al., 2008; PALÁCIO et al., 2008 and SILVA; SACOMANI, 2001) have applied the varimax rotation to get a better and more explicit assignment of water quality variables to PCs. Table 1 presents the loadings of the variables after applying the varimax rotation at both areas A1 and A2. These components express the relationship between the factors and the variables and identify those variables with higher loadings in each component. The most significant variables are identified by the elevated factors loadings.

On A1, $\mathrm{VF}_{1}$, which explains $51.79 \%$ of the variance, is highly and positively (loadings $>0.88$ ) driven by $\mathrm{EC}, \mathrm{Na}^{+}, \mathrm{Cl}^{-}$and $\mathrm{Mg}^{2+}$ (Table 1). It can be interpreted as evidence of the dissolution of geological soil components (BRODNJAK-VONCINA et al., 2002). $\mathrm{VF}_{2}$ (25.44\% of the variance) is mainly driven by $\mathrm{pH}$ and $\mathrm{HCO}_{3}^{-}$, (loadings $>0.85$ ); which may be attributed to the level of acidity of water. The relationship between $\mathrm{pH}$ and $\mathrm{HCO}_{3}{ }^{-}$is such that acidic water has low concentrations of $\mathrm{HCO}_{3}^{-}$while alkaline water has high concentrations of $\mathrm{HCO}_{3}^{-}$. This relation is discussed in detail by Hermes and Silva (2002). $\mathrm{VF}_{3}$ has a strong positive loading on $\mathrm{NO}_{3}{ }^{-}($load $=0.97)$ and a low to moderate loading on the other parameters and is thus a purely organic pollution indicator variable. $\mathrm{VF}_{3}$ represents the sources of anthropogenic pollution; in particular, water pollution originating from human and animal excreta. The well is located near a settlement without sewage treatment where the texture of the soil is coarse. Septic tanks, which are located near wells and are sometimes left open, are associated with a lack of sanitary protection and often cause nitrate contamination (VARNIER; HIRATA, 2002; AQUINO et al. 2008; ANDRADE et al., 2009). 
Table 1 - A summary of the results of the three principal components analyses for A1 (uncultivated area) and A2 (irrigated area). Also presented are the loadings of the different variables following varimax rotation

\begin{tabular}{|c|c|c|c|c|c|c|c|c|c|}
\hline \multirow{3}{*}{$\mathrm{N}^{\circ}$} & \multirow{3}{*}{ Variables } & \multicolumn{3}{|c|}{ A1 } & \multirow{3}{*}{$\mathrm{C}^{*}$} & \multicolumn{3}{|c|}{$\mathrm{A} 2$} & \multirow{3}{*}{$\mathrm{C}^{*}$} \\
\hline & & \multicolumn{3}{|c|}{ Principal Components } & & \multicolumn{3}{|c|}{ Principal Components } & \\
\hline & & $\mathrm{VF}_{1}$ & $\mathrm{VF}_{2}$ & $\mathrm{VF}_{3}$ & & $\mathrm{VF}_{1}$ & $\mathrm{VF}_{2}$ & $\mathrm{VF}_{3}$ & \\
\hline 1 & $\mathrm{Na}^{+}\left(\mathrm{mmol}_{\mathrm{c}} \mathrm{L}^{-1}\right)$ & 0.96 & -0.18 & -0.07 & 0.97 & 0.92 & -0.13 & -0.10 & 0.87 \\
\hline 2 & $\mathrm{CEa}\left(\mathrm{dS} \mathrm{m}{ }^{-1}\right)$ & 0.97 & -0.15 & -0.01 & 0.97 & 0.91 & 0.08 & -0.12 & 0.85 \\
\hline 3 & $\mathrm{Cl}^{-}\left(\mathrm{mmol}_{\mathrm{c}} \mathrm{L}^{-1}\right)$ & 0.96 & -0.21 & -0.09 & 0.97 & 0.79 & -0.01 & 0.04 & 0.63 \\
\hline 4 & $\mathrm{Mg}^{2+}\left(\mathrm{mmol}_{\mathrm{c}} \mathrm{L}^{-1}\right)$ & 0.88 & 0.10 & 0.34 & 0.89 & 0.78 & 0.45 & 0.01 & 0.80 \\
\hline 5 & $\mathrm{pH}$ & -0.26 & 0.88 & -0.07 & 0.85 & - & - & - & - \\
\hline 6 & $\mathrm{HCO}_{3}^{-}\left(\mathrm{mmol}_{\mathrm{c}} \mathrm{L}^{-1}\right)$ & 0.00 & 0.94 & -0.06 & 0.88 & - & - & - & - \\
\hline 7 & $\mathrm{NO}_{3}^{-}\left(\mathrm{mg} \mathrm{L}^{-1}\right)$ & 0.01 & -0.11 & 0.98 & 0.98 & 0.06 & 0.97 & -0.01 & 0.95 \\
\hline 8 & $\mathrm{~K}^{+}\left(\mathrm{mmol}_{\mathrm{c}} \mathrm{L}^{-1}\right)$ & - & - & - & - & 0.84 & 0.25 & 0.07 & 0.77 \\
\hline 9 & $\mathrm{Ca}^{2+}\left(\mathrm{mmol}_{\mathrm{c}} \mathrm{L}^{-1}\right)$ & - & - & - & - & -0.03 & -0.01 & 0.99 & 0.99 \\
\hline & Eigenvalues & 3.63 & 1.78 & 1.11 & - & 3.60 & 1.24 & 1.02 & - \\
\hline & variance explained & 51.79 & 25.44 & 15.84 & - & 51.48 & 17.68 & 14.56 & - \\
\hline$\% \mathrm{c}$ & umulative variance & 51.79 & 77.23 & 93.06 & - & 51.48 & 69.16 & 83.72 & - \\
\hline
\end{tabular}

* C: Communalities - upper to 0.5 means that, the correspondent load factor reproduce more than $50 \%$ of variance explained by correspondent variable; VF - varimax factor

On A2, the first component explains 51.48\% of total variance and is mainly driven by $\mathrm{EC}, \mathrm{Na}^{+}, \mathrm{K}^{+}$, $\mathrm{Cl}^{-}$and $\mathrm{Mg}^{2+}$. The interpretation for this component for $\mathrm{A} 2$ is very similar to that for $\mathrm{VF}_{1}$ for $\mathrm{A} 1$, namely that it is evidence of the dissolution processes of the soil. Although the variances accounted by the first components of $\mathrm{A} 1$ and $\mathrm{A} 2$ are similar (51\%), the variables loadings that define $\mathrm{VF}_{1}$ in $\mathrm{A} 2$ are less positive. This can be explained by the inclusion of the $\mathrm{K}^{+}$ion in this component. $\mathrm{K}^{+}$ions are in the fertilizer and were applied at rates of $36 \mathrm{~kg} \mathrm{ha}^{-1}$ of $\mathrm{K}$ in A2. Since all these variables represent dissolution of soil constituents, the $\mathrm{VF}_{1}$ 's in both areas can also represent the hydrochemical process (BRODNJAK-VONCINA et al., 2002).

$\mathrm{VF}_{2}$ for $\mathrm{A} 2$ is strongly and positively (loading $=0.97$ ) related only with $\mathrm{NO}_{3}^{-}$, due to the agriculture activities occurring in the area. Organic fertilizer and manure are used heavily in A2 to meet the nutritional needs of the coconuts grown there. In total, $80 \mathrm{~kg} \mathrm{ha}^{-1}$ of $\mathrm{N}$ as urea and $430 \mathrm{~kg} \mathrm{ha}^{-1}$ farmyard manure were applied. Also importantly, no human settlements were found in A2, (ANDRADE et al., 2009). From Table 1, can be see that $\mathrm{VF}_{3}$ is strongly driven by $\mathrm{Ca}^{2+}(\mathrm{load}=0.99)$. This high load is attributed to the application of $1800 \mathrm{~kg} \mathrm{ha}^{-1} \mathrm{ano}^{-1}$ of $\mathrm{CaCO}_{3}$ to lower the acidity of the soil $(\mathrm{pH}<4.5)$ (AQUINO et al., 2008).

To better understand the role of the most significant ions (those that had the highest loads) in the water quality of the two studied areas, we performed individual analyses on $\mathrm{Na}^{+}, \mathrm{Cl}^{-}$and $\mathrm{NO}_{3}^{-}$.

\section{Sodium ion $\left(\mathrm{Na}^{+}\right)$}

The highest concentrations of $\mathrm{Na}^{+}$in groundwater at A1 were found in well P6 (Figure 2B). These concentrations were higher than the limits set by the national standards for human consumption. According to Regulation № 518/2004 (BRASIL, 2004) and Resolution № 357 of the CONAMA (National Environmental Council) (BRASIL, 2005), the acceptable limits of sodium for human consumption is $200 \mathrm{mg} \mathrm{L}^{-1}$. In opposite, wells (P1, P2, P5, P7, P8 and P9) are in compliance with the standards for human consumption according to cited Regulation 518/2004.

Unlike the other wells, P6 accumulated sodium rapidly over time, despite having the largest amount of stored water (to a depth of $\sim 9.30 \mathrm{~m}$ ) over the studied period. It has been considered that the rapidly rising sodium concentration was related to the characteristics of the local soil. Unfortunately, the soil was alluvial, formed in layers by deposition, and thus we could not easily affirm the relationship between the characteristics of the local geology and the concentration of sodium in the groundwater (AQUINO et al., 2008).

Wells P3 and P4, which are located in A2 (Figure 2C), also had $\mathrm{Na}^{+}$concentrations that were lower than the standards 
for human consumption. We attributed the low sodium concentrations to the low leaching fraction of this ion in the deeper layers, since the irrigation water had a much lower $\mathrm{Na}^{+}$ concentration (32.66 $\mathrm{g} \mathrm{L}^{-1}$ ) (LOBATO et al., 2008).
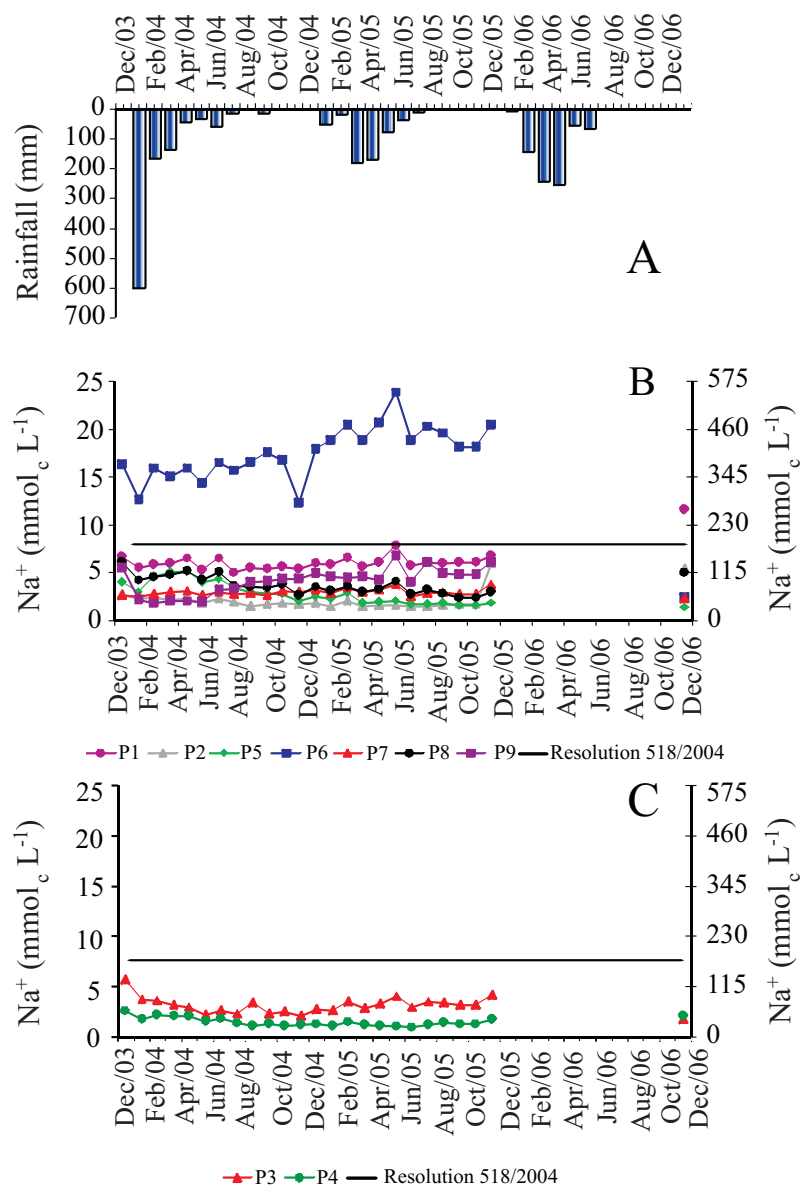

Figure 2 - Precipitation and temporal variability of $\mathrm{Na}^{+}$in wells in $\mathrm{A} 1(\mathrm{~B})$ and $\mathrm{A} 2$ (C)

\section{Chloride ion ( $\mathrm{Cl}$ )}

The concentrations of $\mathrm{Cl}^{-}$measured in the wells in A1 and $\mathrm{A} 2$ are shown in Figure 3. For both areas, the highest concentration occurred in December of 2004 and 2005, just before the start of the rainfall season (Figure $3 \mathrm{~A}$ ) when the water levels in the wells were low.

Over the time period this study was conducted, well P6 contained the highest $\mathrm{Cl}^{-}$concentration and well P1 the second-highest. The $\mathrm{Cl}^{-}$concentration in $\mathrm{P} 6$ stayed at one to two times the maximum acceptable limit for human consumption ( $250 \mathrm{mg} \mathrm{L}^{-1}$ ) according to the standards stated in Resolution Regulation № 518/2004 (BRASIL, 2004).

Since well P6 is located near a settlement without sewage treatment, we conclude that the high $\mathrm{Cl}^{-}$concentration of the well is due to water pollution originating from the septic tanks. In the inland areas of Brazil, these septic tanks are often constructed without adequate technical and sanitary standards. Varnier and Hirata (2002) identified a strong and negative correlation between the $\mathrm{Cl}^{-}$concentration of groundwater and the distance between the wells and the septic tanks. Palácio et al. (2008) and Andrade et al. (2009) further verified that anthropogenic pollution causes the $\mathrm{Cl}^{-}$ concentration in groundwater to increase.

The $\mathrm{Cl}^{-}$concentrations in wells $\mathrm{P} 3$ and $\mathrm{P} 4$ (Figure 3C) varied similarly over time and were lower than the limit recommended for human consumption by Regulation № 518/2004 (Brazil, 2004). This fact can be explained by the high quality of water used for crop irrigation (47.9 $\mathrm{g} \mathrm{L}^{-1}$ of Cl $\mathrm{Cl}^{-}$) (LOBATO et al., 2008) and the water table is deeper than 7 meters (ANDRADE et al., 2009). The wells in A1 tended to have higher $\mathrm{Cl}^{-}$concentrations because the concentration depended strongly on climate seasonality (dry/wet season).

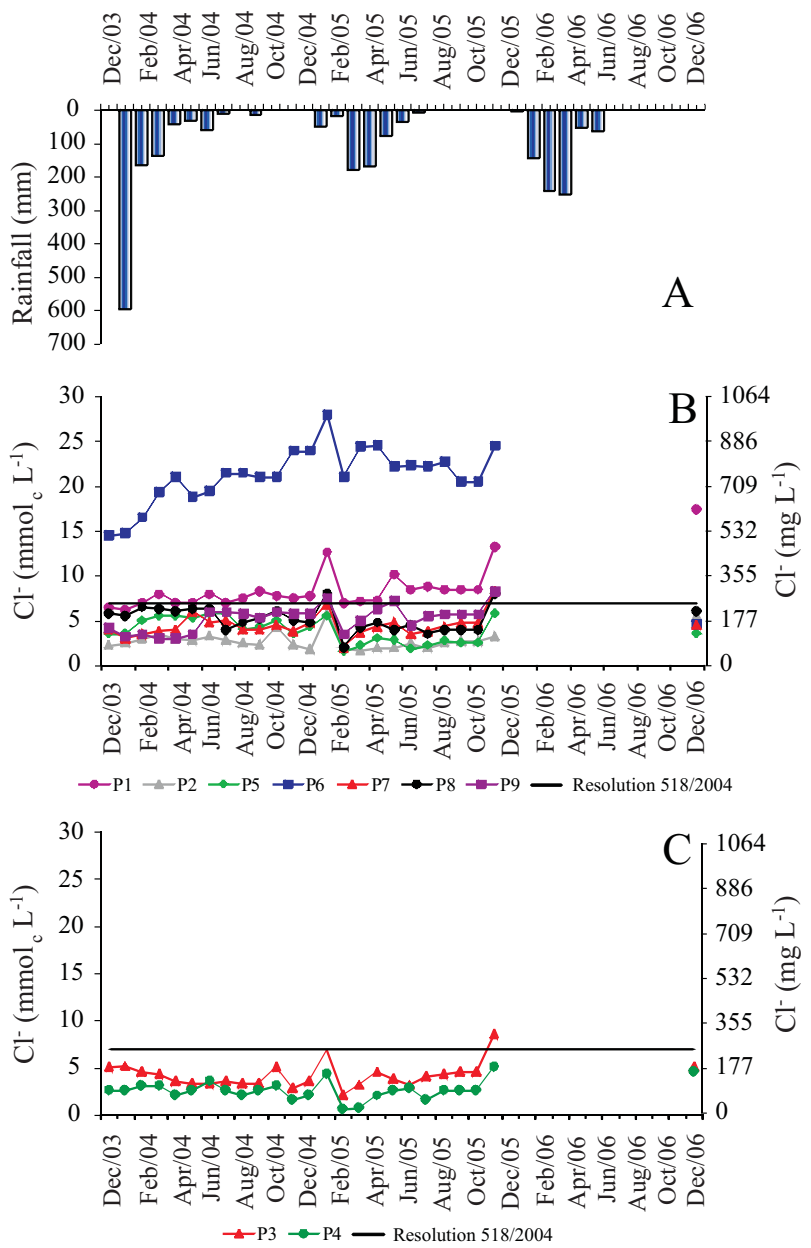

Figure 3 - Precipitation and temporal variability of $\mathrm{Cl}^{-}$in wells in $\mathrm{A} 1(\mathrm{~B})$ and $\mathrm{A} 2(\mathrm{C})$ 


\section{Nitrate Ion}

The $\mathrm{NO}_{3}^{-}$concentrations in the wells in $\mathrm{A} 1$ were different from those in the wells in A2 (Figure 4B and 4C). For the wells located in A1, during the first year of this investigation, well $\mathrm{P} 5$ had the highest $\mathrm{NO}_{3}^{-}$concentration. The concentration was above the standard limit for human consumption (10 $\mathrm{mg} \mathrm{L}^{-1}$ ) established by Regulation № 518/2004 (BRASIL, 2004) and Resolution № 357 of the CONAMA (BRASIL, 2005).

We found that human and animal excreta affected the $\mathrm{NO}_{3}{ }^{-}$concentration in well P5. P5 is located near a settlement without sewage treatment. When the water samples were collected from the well, it was noticed that
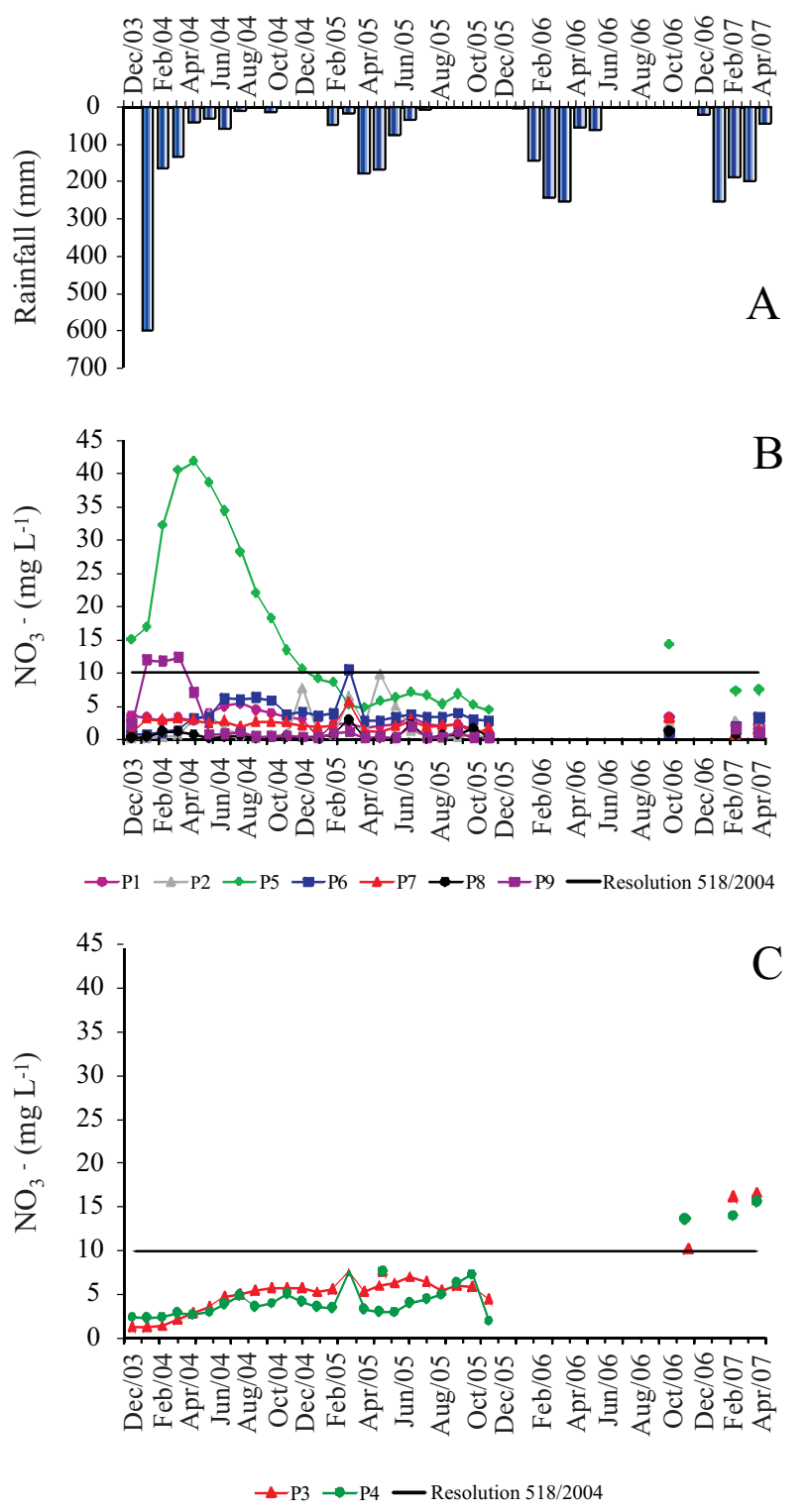

Figure 4 - Precipitation and temporal variability of $\mathrm{NO}_{3}^{-}$in wells in A1 (B) and A2 (C) small domestic animals like chickens and pigs were raised nearby and that there was a septic tank less than $15 \mathrm{~m}$ away. Previous studies have shown that the groundwater in wells is easily contaminated by unsanitary septic tanks in the vicinity, especially in areas where the local soil is sandy (ANDRADE et al., 2009; HELENA et al., 2000; VARNIER; HIRATA, 2002).

Another factor that plays a role in the quality of groundwater is the amount of rainfall. In January 2004, the total amount of rainfall $(500 \mathrm{~mm})$ was $462 \%$ higher than the typical monthly average of rainfall during the rainy season. During the rainfall season, salts easily percolate through the sandy soil that is typical of the area and move toward the deeper layers to rapidly reach the water table (DOWN et al., 2008).

The $\mathrm{NO}_{3}^{-}$concentrations in the other wells in A1 (P1, P2, P6 and P8) displayed similar temporal variability behaviors as that in well P5, as shown in Figure 4B, and were in compliance with the standard limit for human consumption (BRASIL, 2005).

The $\mathrm{NO}_{3}^{-}$concentrations in wells P3 and P4 located in A2 rose with time (Figure 4C). After November 2006, these concentrations stayed above the standard limit of human consumption $\left(10 \mathrm{mg} \mathrm{L}^{-1}\right)$. The highest concentrations in P3 and P4 occurred in May 2007 (17.10 $\mathrm{mg} \mathrm{L}^{-1}$ in $\mathrm{P} 4$ and $19.40 \mathrm{mg} \mathrm{L}^{-1}$ in $\mathrm{P} 3$ ) and were $71 \%$ and $94 \%$ above the standard limit, respectively. Since the nitrate concentration increased only in P3 and P4, it has been assumed that irrigation management might play a vital role in the contamination of groundwater (FENG et al., 2005) and that the sandy texture of the local soil and the application of nitrogen and organic mineral fertilizers serve to increase the concentration of $\mathrm{NO}_{3}^{-}$over time. Our findings therefore suggest that current irrigation management methods in the fields of the Irrigated District of Baixo Acaraú are inadequate.

\section{Conclusions}

In both areas, the best fit model was one that was composed of three components and explained $83.72 \%$ and $93.06 \%$ of the total variance for the areas with irrigated culture and areas with no cultivation, respectively. The determinant factors of the quality of the groundwater in both areas were geology and anthropogenic pollution. In the areas with irrigated culture, the anthropogenic pollution was from nitrated fertilizers and the acidity of the local soil acidity. In the non-cultivated areas, the anthropogenic pollution was due to the use of septic tanks with no sanitation standards or treatments. The current management methods of irrigation contribute to unhealthily high levels of nitrates in groundwater. 


\section{Acknowledgments}

We would like to thank the Conselho Nacional de Ciência e Tecnologia - CNPq for funding.

\section{References}

ANDRADE, E. M et al. Impacto da lixiviação de nitrato e cloreto no lençol freático sob condições de cultivo irrigado. Ciência Rural, v. 39, n. 01, p. 88-95, 2009.

ANDRADE, E. M. et al. Fatores determinantes da qualidade das águas superficiais na bacia do Alto Acaraú, Ceará, Brasil. Ciência Rural, v. 37, n. 06, p. 1791-1797, 2007.

ANDRADE, E. M. et al. Land use effects in groundwater composition of an alluvial aquifer (Trussu River, Brazil) by multivariate techniques. Environmental Research, v. 106, n. 02, p. 170-177, 2008.

AQUINO, D. N. et al. Impacto do manejo da irrigação sobre os recursos solo e água. Revista Ciência Agronômica, v. 39, n. 02, p. $225-232,2008$.

BRASIL. Ministério da Saúde. Portaria n ${ }^{\circ} 518$, de 25 de março de 2004. Estabelece os procedimentos e responsabilidades relativos ao controle e vigilância da qualidade da água para consumo humano e seu padrão de potabilidade, e dá outras providências. Diário Oficial da República Federativa do Brasil. Brasília, 26 mar. 2004. Seção 1.

BRASIL. Ministério do Meio Ambiente. Resolução CONAMA No 357 de 17 de março de 2005. Dispõe sobre classificação dos corpos de água e diretrizes ambientais para o seu enquadramento, bem como estabelece as condições e padrões de lançamento de efluentes, e dá outras providências. Brasília, 2005. Disponível em: <http://www.mma.gov.br/conama/res/res05/res35705.pdf.> Acesso em: 09 abr. 2007.

BRODNJAK-VONCINA, D. et al. Chemometrics characterisation of the quality of river water. Analytica Chimica Acta, v. 462, n. 01, p. 87-100, 2002.

DILLON, W. R.; GOLDSTEIN, M. Multivariate analysis methodos and applications. New York: John Wiley e Sons, 1984. $587 \mathrm{p}$.

DOWD, B. M. et al. Agricultural nonpoint source water pollution policy: The case of California's Central Coast. Agriculture, Ecosystems and Environment, v. 128, n. 03, p. 151-161, 2008.

FENG Z. Z.; WANG, X. K.; FENG, Z. W. Soil N and salinity leaching after the autumn irrigation and its impact on groundwater in Hetao Irrigation District, China. Agricultural Water Management, v. 71, n. 02, p. 131-143, 2005.
HAIR JÚNIOR F. et al. Análise Multivariada de Dados. Porto Alegre: Bookman, 2005. 593 p.

HELENA, B. et al. Temporal evolution of groundwater composition in an alluvial aquifer (Pisuerga river, Spain) by principal component analysis. Water Research, v. 34, n. 03 , p. $807-816,2000$.

HERMES, L. C.; SILVA, A. S. Parâmetros básicos para avaliação da qualidade das águas: análise e seu significado ambiental. Jaguariúna, 2002. 32 p.

LOBATO, F. A. de O. et al. Sazonalidade na qualidade da água de irrigação do Distrito Irrigado Baixo Acaraú, Ceará. Revista Ciência Agronômica, v. 39, n. 01, p. 167-172, 2008.

MATIAS FILHO, J. et al. Estudos e Pesquisas para avaliação de riscos potenciais de drenagem e/ou salinidade na área prioritária do projeto de irrigação Baixo Acaraú. Fortaleza: UFC, 2001, 27 p. (Relatório Técnico).

MINDRISZ, A. C. Avaliação da contaminação da água subterrânea de poços tubulares por combustíveis fósseis, no município de Santo André, São Paulo: Uma contribuição à gestão ambiental. 2006. $254 \mathrm{f}$. Tese (Doutorado em Tecnologia Nuclear) - Instituto de Pesquisas Energéticas e Nucleares, Universidade de São Paulo, São Paulo, 254p.

MOLINA, M. D. B. et al. Hipertensão arterial e consumo de sal em população urbana. Revista de Saúde Pública, v. 37, n. 06, p. 743-750, 2003.

MONTEIRO, V. P.; PINHEIRO, J. C. V. Critério para implantação de tecnologias de suprimentos de água potável em municípios cearenses afetados pelo alto teor de sal. Revista de Economia Rural, v. 42, n. 02, p. 365-387, 2004.

MULLER, K. et al. A critical review of the influence of effluent irrigation on the fate of pesticides in soil. Agriculture, Ecosystems and Environment, v. 120, n. 02/04, p. 93-116, 2007.

NORUSIS, M. J. SPSS Base System User s Guide. Chicago: SPSS Inc, 1990.520 p.

PALÁCIO, H. de A. Q. et al. Selection of the determinates Trussu River water quality factors using multivariable analysis. Geographia Technica, n. 01, p. 74-81, 2008.

RICHARDS, L. A. Diagnosis and improvement of saline and alkali soils. Washington DC.: US Department of Agricultural, 1954. 160 p. (USDA Agricultural Handbook, 60).

SILVA, A. M. M.; SACOMANI, L. B. Using chemical and physical parameters to define the quality of Pardo river water (Botucatu- SP-Brasil). Water Research, v. 35, n. 06, p. 1609- 1616, 2001.

VARNIER, C.; HIRATA, R. Contaminação da água subterrânea por nitrato no parque ecologico do Tietê - São Paulo, Brasil. Revista Águas Subterrâneas, v. 16, p. 97-104, 2002. 